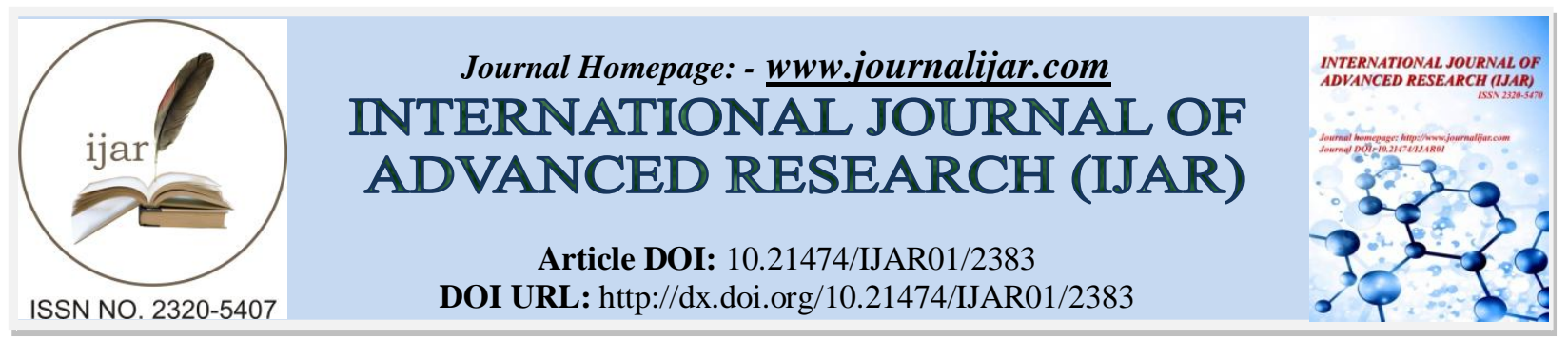

RESEARCH ARTICLE

\title{
MIDWIFERY STUDENTS' KNOWLEDGE AND OPINIONS ABOUT, AND BEHAVIORS TOWARDS GENETICALLY MODIFIED FOODS.
}

Zeliha Burcu Yurtsal.

Assistant Professor, Midwifery Department, Faculty of Health Sciences, Cumhuriyet University, Sivas, Turkey, 58140 .

\section{Manuscript Info}

Manuscript History

Received: 19 October 2016

Final Accepted: 20 November 2016

Published: December 2016

Key words:-

Genetically Modified Foods;

Knowledge, Opinions, Behaviors;

Midwifery Students

\section{Abstract}

Raising people's awareness of these genetically modified foods is very important. Therefore, to protect the members of the society against the risks of these foods, health professionals take great responsibility. This descriptive study was conducted with midwifery students attending the Faculty of Health Sciences, Cumhuriyet University. The population of the study comprised 307 students studying at a midwifery department during the 2015/2016 academic year. There was a significant relationship between their knowledge levels and views about genetically modified foods such as "I approve the production of foods with genetically modified seeds in Turkey", "Production of GM foods poses risks for all living creatures", "I think that GM crops have carcinogenic properties" "I think that GM crops are harmful to the quality of life of people" $(\mathrm{p}<0.05)$. In conclusion, this present study shows that the participating midwifery students' knowledge of genetically modified foods was insufficient. However, their views on and behaviors towards genetically modified foods and consumption status were satisfactory. That midwifery students who are to provide people with education and counseling on nutrition in order to protect and improve mothers', infants' and communities' health have adequate and correct knowledge about genetically modified foods is of great importance.

Copy Right, IJAR, 2016,. All rights reserved.

\section{Introduction:-}

Food, one of the most important products of consumption, is essential to survive ${ }^{1}$. Although, genetically-modified foods are expected to be a solution for the food crises in the world, they are assumed to pose a danger for human health, environment and biodiversity ${ }^{2}$.

Genetically modified organisms (GMOs) are defined as organisms whose genome is altered by the techniques of genetic engineering in a way that its DNA contains one or more genes not naturally found there. Such techniques are first used to create GM plants and then to grow (GM) food crops. Thanks to GM foods, many of the world's hunger and malnutrition problems seem to be solved. What is more, these foods will help protect and preserve the environment, because they increase yield and reduce the use of chemical pesticides and herbicides ${ }^{3}$. On the other hand, genetically modified foods (GMFs) can pose a threat for the environment or human health ${ }^{4,5,6}$.

Corresponding Author:- Zeliha Burcu Yurtsal.

Address:- Assistant Professor, Midwifery Department, Faculty of Health Sciences, Cumhuriyet

University, Sivas, Turkey, 58140 
Among the GMO-associated risks are toxic or allergic effects such as plants' becoming single type due to the loss of genetic diversity, loss of diversity in nature, transmission of modified genes to plants in the land where genetically modified plants are not grown, extinction of beneficial insects, resistance acquired by some insect species to toxins over time, resistance development to antibiotics due to environmental effects such as excessive pesticide use, transmission of the DNA to human cells through foods consumed, and transfer of these DNA transmissions to the next generations ${ }^{7}$.

Worldwide, GMOs are cultivated in 125 million hectares of land. Of all the countries cultivating GMOs, the United States takes the lead. Of the GMO products, the ones grown most are soybean, corn and cotton ${ }^{8}$. The first legislation on GMOs in Turkey was made on 26 October 2009. According to this regulation, the cultivation of GM crops is banned in Turkey. If the amount of GMO in food is more than $0.9 \%$, it is mandatory to state that the food contains GMO in the label ${ }^{9}$.

Today, studies on GMOs whose importance is increasing with each passing day have revealed that people's attitudes and behaviors towards GMOs vary from one country to another ${ }^{10}$. Raising people's awareness of these genetically modified foods is very important. Therefore, to protect the members of the society against the risks of these foods, health professionals take great responsibility. They should warn ordinary people about the safe consumption and health risks of foods and precautions to be taken, and provide guidance for them ${ }^{11}$. This study aimed to determine midwifery students' knowledge and views about and behaviors towards genetically modified foods because they are to provide education and counseling about nutrition for people in the community in which they will work after graduation.

\section{Materials and Methods:-}

This descriptive study was conducted with midwifery students attending the Faculty of Health Sciences, Cumhuriyet University. The population of the study comprised 307 students studying at a midwifery department during the 2015/2016 academic year.

No sampling method was implemented; 270 students who agreed to participate in the study were included in the study. Before the study was performed, necessary permission was obtained from the school administration, and written consents were obtained from the participating students. Data were collected through face-to-face interviews using a questionnaire developed by the researchers after a literature review ${ }^{12,13}$. For the analysis of the data obtained, frequency distribution and chi-square analysis were performed by using the SPSS 22.0. P-values $<0.05$ were considered to be statistically significant.

\section{Results:-}

The mean age of the students participating in the study was $20.8 \pm 1.5$. Of the participants, $38.9 \%$ were from the central Anatolia region and $95.6 \%$ had health insurance. Of the participants, 30.4\% were knowledgeable about genetically modified foods. Of them, $69.6 \%$ obtained this information through the social media, and $92.2 \%$ were knowledgeable about the genetically modified foods included in the food they bought. While $10.7 \%$ of the participants thought that the safety of food additives was ensured, $76.7 \%$ of them thought that the main source of products including GMOs was agriculture. Some socio-demographic characteristics of the participating midwifery students and their knowledge and views about genetically modified foods are listed in Table 1.

Table 1:- Socio-demographic characteristics of the participants and their knowledge and views about genetically modified foods $(\mathrm{n}=270)$.

\begin{tabular}{|l|l|l|}
\hline VARIABLES & $\mathbf{n}$ & $\mathbf{\%}$ \\
\hline Age & $20.82 \pm 1.51$ \\
\hline Region of birth & \multicolumn{2}{l|}{} \\
\hline Marmara Region & 17 & 6.3 \\
\hline Aegean Region & 13 & 4.8 \\
\hline Central Anatolia & 105 & 38.9 \\
\hline Black Sea Region & 31 & 11.5 \\
\hline Mediterranean Region & 50 & 18.5 \\
\hline Eastern Anatolia & 23 & 8.5 \\
\hline South East Anatolia & 31 & 11.5 \\
\hline Social Security & \multicolumn{2}{|l|}{} \\
\hline
\end{tabular}




\begin{tabular}{|l|l|l|}
\hline Yes & 258 & 95.6 \\
\hline No & 12 & 4.4 \\
\hline Household monthly income(\$) & 95 & 35.2 \\
\hline$\leq \$ 430$ & 105 & 38.9 \\
\hline$\$ 431-\$ 761$ & 70 & 25.9 \\
\hline$>\$ 761$ & 82 & 30.4 \\
\hline Knowledge of genetically modified foods & 188 & 69.6 \\
\hline Yes & \multicolumn{2}{|l|}{} \\
\hline No & 56 & 20.7 \\
\hline Source of the Information about genetically modified foods & 188 & 69.6 \\
\hline Midwifery department & 26 & 9.6 \\
\hline Social media & 29 & 10.7 \\
\hline Printed media & 29 & 89.3 \\
\hline Safety of genetically modified foods use is ensured & 241 \\
\hline Yes & \multicolumn{2}{|l|}{} \\
\hline No & 249 & 92.2 \\
\hline Being aware of the genetically modified foods in the food purchased & 21 & 7.8 \\
\hline Yes & \multicolumn{2}{|l|}{} \\
\hline No & \multicolumn{2}{|l|}{} \\
\hline Continuation of Table 1 & 207 & 76.7 \\
\hline Mainly sectors that it includes genetically modified foods & 17 & 6.3 \\
\hline Agriculture & 28 & 10.4 \\
\hline Animals & 18 & 6.7 \\
\hline Health & 270 & 100.0 \\
\hline No comment & \\
\hline Total & \multicolumn{2}{|l|}{} \\
\hline
\end{tabular}

Of the participating midwifery students, $80.7 \%$ agreed with the statement "Production of GM foods poses risks for all living creatures", 9.3\% agreed with the statement "I do not mind consuming GM foods" and $82.6 \%$ agreed with the statement "I think that GM foods have adverse effects on human health". The midwifery students' knowledge and views on genetically modified foods are given in Table 2 .

Table 2:- Knowledge and views about genetically modified foods $(n=270)$.

Knowledge and views about genetically modified foods

I approve the production of foods with genetically modified seeds in Turkey

Yes

No

I approve the feeding of animals with genetically modified feeds in Turkey.

Yes

No

I approve Turkey's importing genetically modified seeds

Yes

No

\begin{tabular}{|c|c|}
\hline n & $\%$ \\
\hline 24 & 8.9 \\
\hline 246 & 91.1 \\
\hline
\end{tabular}

\begin{tabular}{l|l|}
15 & 5.6 \\
\hline & 94.4 \\
\hline
\end{tabular}

\begin{tabular}{l|l}
255 & 94.4
\end{tabular}

I think that the food I buy now would include genetically modified products.

Yes

No

\begin{tabular}{|l|l|}
\hline 17 & 6.3 \\
\hline
\end{tabular}

\begin{tabular}{l|l}
1753 & 93.7
\end{tabular}

I think that society is adequately informed about genetically modified foods

\begin{tabular}{|l|l|l|l}
\hline Yes & 31 & 11.5 \\
\hline No & 239 & 88.5 \\
\hline
\end{tabular}

Production of GM foods poses risks for all living creatures.

\begin{tabular}{|l|l|l}
\hline Yes & 218 & 80.7 \\
\hline
\end{tabular}

\begin{tabular}{|l|l|l}
\hline No & 52 & 19.3
\end{tabular}

I approve of the genetic modification of food to eliminate hunger in the world

Yes

No

\begin{tabular}{|l|l|}
\hline 28 & 10.4 \\
\hline 242 & 89.6
\end{tabular}




\begin{tabular}{|c|c|c|}
\hline \multicolumn{3}{|c|}{ I approve of the genetic modification of foods to enrich their nutritional content } \\
\hline Yes & 35 & 13.0 \\
\hline No & 235 & 87.0 \\
\hline \multicolumn{3}{|c|}{$\begin{array}{l}\text { I approve that foods can be genetically modified in order to extend their shelf life and to make them more } \\
\text { resistant to insects and pesticides }\end{array}$} \\
\hline Yes & 36 & 13.3 \\
\hline No & 234 & 86.7 \\
\hline \multicolumn{3}{|c|}{ I think that if a food contains GMOs, this should always be indicated on the label } \\
\hline Yes & 208 & 77.0 \\
\hline No & 62 & 23.0 \\
\hline \multicolumn{3}{|c|}{ I do not mind consuming GM foods } \\
\hline Yes & 25 & 9.3 \\
\hline No & 245 & 90.7 \\
\hline \multicolumn{3}{|c|}{ I do not mind other people's consuming GM foods } \\
\hline Yes & 26 & 9.6 \\
\hline No & 244 & 90.4 \\
\hline \multicolumn{3}{|c|}{ I think that GM foods have adverse effects on human health } \\
\hline Yes & 223 & 82.6 \\
\hline No & 47 & 17.4 \\
\hline \multicolumn{3}{|c|}{ I think that GM crops have carcinogenic properties. } \\
\hline Yes & 224 & 83.0 \\
\hline No & 46 & 17.0 \\
\hline \multicolumn{3}{|c|}{ I think that GM crops adversely affect the natural environment. } \\
\hline Yes & 224 & 83.0 \\
\hline No & 46 & 17.0 \\
\hline \multicolumn{3}{|c|}{ I think that GM crops are harmful to the quality of life of people. } \\
\hline Yes & 223 & 82.6 \\
\hline No & 47 & 17.4 \\
\hline
\end{tabular}

We investigated the participants' knowledge and views about the genetically modified foods that are hazardous to health and determined that they were not knowledgeable enough about genetically modified foods and consumption of genetically modified foods. However, there was a significant relationship between their knowledge levels and views about genetically modified foods such as "I approve the production of foods with genetically modified seeds in Turkey", "Production of GM foods poses risks for all living creatures", "I think that GM crops have carcinogenic properties" "I think that GM crops are harmful to the quality of life of people" $(p<0.05)$. The data related to the level of knowledge and views about genetically modified foods and consumption of genetically modified foods status are given in Table 3.

Table 3:- The participants' knowledge and views about genetically modified foods, and their consumption status

\begin{tabular}{|c|c|c|c|c|c|}
\hline & \multicolumn{4}{|c|}{ Consumption status } & \multirow[t]{2}{*}{ Pearson Chi-Square } \\
\hline $\begin{array}{l}\text { Genetically modified } \\
\text { foods }\end{array}$ & Yes $(n=249)$ & $\%$ & No $(n=21)$ & $\%$ & \\
\hline \multicolumn{6}{|c|}{ I approve the production of foods with genetically modified seeds in Turkey } \\
\hline Yes & 18 & 7.2 & 6 & 28.6 & \multirow[t]{2}{*}{0.001} \\
\hline No & 231 & 92.8 & 15 & 71.4 & \\
\hline \multicolumn{6}{|c|}{ I approve the feeding of animals with genetically modified feeds in Turkey } \\
\hline Yes & 12 & 4.8 & 3 & 14.3 & \multirow[t]{2}{*}{0.069} \\
\hline No & 237 & 95.2 & 18 & 85.7 & \\
\hline \multicolumn{6}{|c|}{ I approve Turkey's importing genetically modified seeds } \\
\hline Yes & 14 & 5.6 & 3 & 14.3 & \multirow[t]{2}{*}{0.117} \\
\hline No & 235 & 94.4 & 18 & 85.7 & \\
\hline \multicolumn{6}{|c|}{ I think that the food I buy now would include genetically modified products } \\
\hline Yes & 200 & 80.3 & 12 & 57.1 & \multirow[t]{2}{*}{0.013} \\
\hline No & 49 & $\begin{array}{ll}19.7 \\
\end{array}$ & 9 & \begin{tabular}{|l|l|}
42.9 \\
\end{tabular} & \\
\hline
\end{tabular}




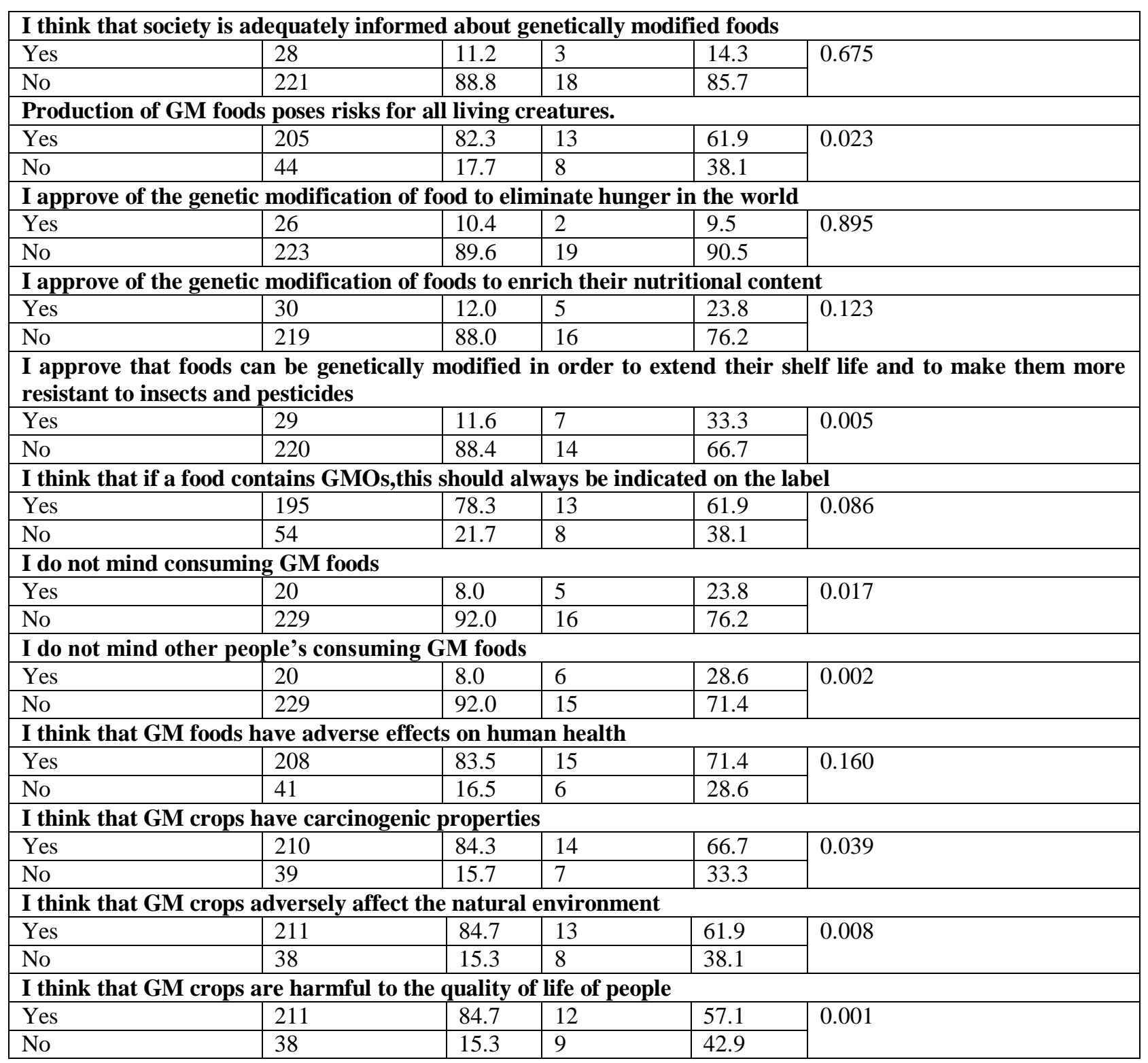

\section{Discussion:-}

Over the past years, reactions of the public to GM foods have varied to a great extent ${ }^{14,15,16,17}$, and not only potential positive attributes (e.g. lesser amounts of pesticides) but also negative attributes (e.g.unnatural) have been identified $^{18,19,20}$.

In a study, health college students' knowledge of GMOs was determined as inadequate ${ }^{13}$. In the same study, when the participants were asked why their knowledge of GMOs was not adequate, $72.2 \%$ of them said that they never read a scientific publication on this subject whereas $81.3 \%$ of them said that this topic was not included in their curriculum $^{13}$. In another study, while the medical students' perceptions of risk of genetically modified foods were satisfactory, their knowledge of these foods was insufficient. When the participants were asked how they first heard of genetically modified organisms, of them, $67.8 \%$ said on TV or radio, and $8.4 \%$ said from this present survey. While $67.8 \%$ of the participants said they first heard of genetically modified organisms on TV or radio, $8.4 \%$ said they first encountered this concept in this present survey. In Demir's study, these rates were 42.0\% and 29.0\% respectively ${ }^{21}$. In Utkualp et al. study, while $90.6 \%$ of the participants said they first heard of genetically modified organisms on TV or radio, $7.1 \%$ of them said that the source of their knowledge of GMOs was their school ${ }^{22}$. In the present study, midwifery department students' knowledge of genetically modified foods was found to be low 
(30.4\%). While only $20.7 \%$ of them said that the source of their knowledge of GMOs was their school, $69.6 \%$ of them stated that their source was the social media.

In Turkey, the cultivation of GM crops is banned ${ }^{23}$. In a study, $62.4 \%$ of the medical students did not approve of the production of genetically modified organisms in Turkey ${ }^{12}$. In the present study, $91.1 \%$ of the midwifery students did not approve of the production of genetically modified organisms in Turkey.

In a study, $54.4 \%$ of the medical students did not mind consuming foods including GMOs. In Demir et al.'s study conducted with people from various professions, $85.6 \%$ of the respondents stated that they would not consume GMO products ${ }^{21}$. In Ergin et al.'s study, this rate was $66.7 \%{ }^{7}$. In another study, the participating health college students were determined to have a negative perception of $\mathrm{GMOs}^{22}$. In the present study, while $90.7 \%$ of the students stated that they would not consume GM foods, $90.4 \%$ of them stated that they would not approve of other people's consuming GM foods, which suggests that the participating students' perception of risk of GM foods for individuals and the society was high.

In another study conducted with medical students, $83.2 \%$ of them assumed that the foods they currently consumed might include GMOs. This rate was $77.7 \%$ in Ergin et al.'s study ${ }^{7}$, and ranged from $62 \%$ to $43.2 \%$ in several studies conducted in European Union countries, China and Indonesia ${ }^{24,25,26}$. The rates determined in Turkey were higher than were those determined in studies performed in other countries ${ }^{12}$. In the present study, of the participating students, $89.3 \%$ stated that they were not sure whether GM foods were safe, and $92.2 \%$ thought that they may have consumed GM foods. The high rate of people who think that they have consumed GMOs in Turkey can be explained by the fact that Turkish people are suspicious of GMOs.

Turkish people's perceptions of risk of GMO technology are also changing. In a study of medical students, $56.9 \%$ of them state that production of genetically modified food poses risk for all living things in nature. This rate is $65.3 \%$ in Ergin et al.'s study'. In Demir et al.'s study, $51.7 \%$ of the nurses and $31.6 \%$ of the physicians indicated that GMOs could lead to health problems ${ }^{21}$. While $60 \%$ of the respondents in Pardo et al.'s study considered that making genetic modifications in food products would pose a risk for people, about half of the European adults considered gene transfer between plant species would pose a risk ${ }^{24}$. In the present study, $80.7 \%$ of the midwifery students stated that the production of GM foods would pose risks for all living creatures.

With the use of the GMO technology, it has become possible to extend foods' shelf life and to produce products more resistant to insects and pesticides. Tomatoes with the extended shelf life were first introduced to the market in the US in 1996, but due to community's lack of interest and poor promotion, they were withdrawn from the market ${ }^{27}$. In a study of medical students, $27.3 \%$ of them approved that foods could be genetically modified in order to extend their shelf life and to make them more resistant to insects and pesticides. In Ergin et al.'s study, this rate was $21.8 \%{ }^{7}$. In the present study, $13.3 \%$ of the participants approved that foods can be genetically modified in order to extend their shelf life and to make them more resistant to insects and pesticides.

The main point in dealing with morality and faith concerns regarding GM crops is the labeling of these products. According to relevant regulations in Turkey, if a product contains more than $0.9 \%$ of GMOs, this should be stated in the label ${ }^{23}$. The rate is the same in European Union countries, except for Norway where this rate is $2 \%{ }^{28}$. Labeling GMOs products may not stop the production of GMOs but chance to people a choice between GM and non-GM foods. Nowadays more than 15 states in the United States are considering such legislation of food labeling ${ }^{29}$. A study conducted with 3002 participants in Belgium, France, the Netherland, Spain and the United Kingdom found that consumers are willing to pay a premium to avoid purchasing rice labeled as genetically modified ${ }^{30}$. In a study of medical students, $84.9 \%$ of them stated that if a food is genetically modified, this should be indicated on the label. In another study, $100 \%$ of the students of a health college think that if a food has GMOs, this should be stated on food labels $^{22}$. In some studies conducted in Turkey, China and Indonesia, it has been reported that mandatory labeling would be appropriate $e^{7,21,26,31}$. In the present study, $77.0 \%$ of the midwifery students think that if a food contains GMOs, this has to be indicated on the label.

In a study, the majority of health college students think that GMFs and GMOs are harmful to human health and they have a negative perception of GMOs ${ }^{22}$. In another study, of the health college students, $74.3 \%$ think that GM crops are harmful to human health, $74.9 \%$ consider GMOs as potentially carcinogen materials, $66.3 \%$ state that limited consumption of GM crops would not pose a risk for human health and 61.5\% consider that GMOs are harmful to the 
natural environment ${ }^{13}$. In the other study, the majority of participants think that GMFs and GMOs are harmful to human health ${ }^{32}$. In another study, of the participants, 54\% think that GMOs are harmful to human health, 33.3\% state that GMOs are harmful to the natural environment ${ }^{33}$. In the present study, of the midwifery students, $82.6 \%$ think that GMO products have adverse effects on human health, $83.0 \%$ state that products with GMOs might be carcinogenic, $83.0 \%$ think that GMOs affect the natural environment negatively and $82.6 \%$ think that products including GMOs are harmful to the quality of life of people.

Inclusion of training activities in education plans aiming to improve students" knowledge of "GMOs" is considered appropriate $^{12}$. A study purposed to assess knowledge related with GMOs and tendency to buy genetically modified food instead of natural food in 745 Polish medical students. The study found that the majority of students neither preferred GMOs food, nor had positive feelings. And it is stated that the students were also not satisfied with the knowledge about GMOs that they obtained from school or university ${ }^{34}$. It is also considered that it would be appropriate to organize campaigns under the leadership of experts to increase the community's awareness of consumption of foods consciously and safely, and to include health workers in these activities ${ }^{12}$. In one study, Xia et al., stated that alarm incident about the safety of GMOs were discussed. And it is stated that emphasize the prompt reaction of media ${ }^{35}$. In another study found that Italian students were not knowledgeable about products with GMOs and avoid to buy genetically modified food ${ }^{36}$. It can be said that health college students were not knowledgeable about products with GMOs and these products' long-term effects on human health. Therefore, it is recommended to conduct further studies aiming to enhance their knowledge of GMOs ${ }^{13}$. Increasing students' awareness of GMOs is also crucial. Therefore, it would be appropriate to give informative lectures about GMOs in schools. In addition, informative activities regarding global policies affecting health can be organized ${ }^{13}$.

\section{Conclusions:-}

In conclusion, this present study shows that the participating midwifery students' knowledge of genetically modified foods was insufficient. However, their views on and behaviors towards genetically modified foods and consumption status were satisfactory. The participants' insufficient knowledge about the issue makes it difficult to giving advise to safety of genetically modified foods. Training of students on this issue who are younger consumers is important for the protection of public health. That midwifery students who are to provide people with education and counseling on nutrition in order to protect and improve mothers', infants' and communities' health have adequate and correct knowledge about genetically modified foods is of great importance.

\section{References:-}

1. Lueck A. M., Kreit B., Falcon R. Foodweb 2020,forces shaping the future of food. PaloAlto, CA:Institute for the Future, available at http://www. iftf.org/uploads/media/SR1255B_FoodWeb2020report_1_.pdf.:( 2010).

2. Hellstein I. Focus on metaphors: the case of Franken food on the web. Journal of Computer-Mediated Communication: 8, available at http:// online library.wiley.com/doi/10.1111/j.1083-6101.2003.tb00218.x/full.: (2003).

3. Montuori P., Triassi M., Sarnacchiaro P. The consumption of genetically modified foods in Italian high school students. Food Quality and Preference: 26: 246-251. http://dx.doi.org/10.1016/j.foodqual.2012: (2012).

4. Jones L. Science, Medicine, and The Future. Genetically Modified Foods. British Medical Journal: 318: 581584: (1999).

5. McLean M.R. The Future Of Food: An Introduction To The Ethical Issues In Genetically Modified Foods. The future of food:legal and ethical challenges. Available at http://www.scu.edu/ethics/practicing/focusareas/medical/conference/presentations/genetically-modifiedfoods.html.: (2005).

6. Whitman D.B. Genetically modified foods:harmful or helpful? April, available at http://www.csa.com/discoveryguides/gmfood/overview.php.: (2000).

7. Ergin I., Gursoy Ş.T., Ocek Z.A., Ciceklioglu M. Information About The Attitudes And Behaviors Of Genetically Modified Organisms In Health Vocational School Students.TAF Prev Med Bull.: 7: 503-508: (2008).

8. Meseri R. Nutrition and Genetically Modified Organisms (GMOs). Armed Forces Medical Bulletin: 7: 455-60: (2008).

9. Anonym.http://www.tarim.gov.tr/Files/mevzuat/yonetmelik_son/GDO_20100428.htm (available at: 15.06.2016). 
10. Hidiroglu S., Onsuz M. F., Kalafat C. E., Karavus M. Umraniye 1. the Health Care Of to Admitted Patients Knowledge, Attitude and Behavior of Genetically Modified Organisms . Firat J. Med.: 18(3): 176-181: (2013).

11. Karadag G., Aydın N., Kayaaslan H. Sensitivity On The Gaziantep University Of Medicine And Nursing Student In The Department Of Food Safety And Read Feedback. TAF Prev Med Bull.: 11(4): 439-446: (2012).

12. Kocak N., Turker T., Kilıc S., Hasde M. Information about the faculty of medicine of genetically modified organisms students, to determine attitudes and behavior. Gulhane Medical Journal: 52: 198-204: (2010).

13. Adana F., Gezer N., Ogut S. Knowledge and Opinions Regarding Genetically Modified Organisms of Health School Students. Journal of the Acibadem University of Health Sciences: 5(4): 276-280: (2014).

14. Gaskell G., Bauer M. W., Durant J., Allum N. Worlds apart? The Reception Of Genetically Modified Foods In Europe And The US. Science: 285: 384-387: (1999).

15. Magnusson M. K., Koivisto H. U. K. Consumer Attitudes Towards Genetically Modified Foods. Appetite.: 39: 9-24: (2002).

16. Moses V. Biotechnology Products And European Consumers. Biotechnology Advances: 17: 647-678: (1999).

17. Staff . U.S. Consumer Attitudes Toward Food Biotechnology,International Food Information Council Foundation. 2000, Retrieved October, from http://www.ific.org.: (2003).

18. Bredahl L. Consumers' Cognitions With Regard To Genetically Modified Foods. Results Of A Qualitative Study In Four Countries. Appetite: 33: 343-360: (1999).

19. Cook A. J., Kerr G.N., Moore K. Attitudes and Intentions Towards Purchasing GM Food. Journal of Economic Psychology: 23: 557-572: ( 2002).

20. Siegrist M. The Influence Of Trust And Perceptions Of Risks And Benefits On The Acceptance Of Gene Technology. Risk Analysis: 20: 195-203: (2000).

21. Demir A., Pala A. Perspective Of The Community To Genetically Modified Organisms. Journal Of Animal Production: 48: 33-43: (2007).

22. Utkualp N., Ozdemir A., Bicer M., Ozdemir B. Attitudes to Genetically Modified Organisms and Food Among University Students, Oxidation Communications: 39,1(1): 384-395: (2016).

23. Anonym. Food and feed Genetically Modified Organisms and Import of Products, Processing, Export, Regulations on the Control and Audit. www. tarim.gov.tr., (available at: 15.06.2016).

24. Pardo R., Midden C., Miller J.D. Attitudes Toward Biotechnology In The European Union. J Biotechnol.: 98: 924: (2002).

25. Huang J., Qiu H., Bai J., Pray C. Awareness, Acceptance Of And Willingness To Buy Genetically Modified Foods In Urban China, Appetite: 46: 144-151: (2006).

26. Februhartanty J., Widyastuti T.N., Iswarawanti D.N. Attitudes Of Agricultural Scientists In Indonesia Towards Genetically Modified Foods. Asia Pac J Clin Nutr.: 16 : 375-380: (2007).

27. Bayrac A.T., Baloglu M.C., Kalemtas G., Kavas M. Genetically Modified Organisms. Ankara: METU Development Foundation Publishing: 9: (2007).

28. Maekawa F., Macer D. How Japanese Students Reason About Agricultural Biotechnology. Sci Eng Ethics: 10: 705-716: (2004).

29. Wohlers A. E. Labeling of Genetically Modified Food: Closer to Reality in the United States? Politics and the Life Sciences: 32(1): 73-84: (2013).

30. Delwaide A.C., Nally L.L., Dixon B.L., Danforth D.M., Nayga R.M. van Loo E.J., Verbeke W. Revisiting GMOs: Are There Differences in European Consumers' Acceptance and Valuation for Cisgenically vs Transgenically Bred Rice? PLos One: 10 (5): e0126060: (2015).

31. Lan L. Chinese Public Understanding Of The Use Of Agricultural Biotechnology. A Case Study From Zhejiang Province Of China. Lü / J Zhejiang Univ Science B.: 7:257-266: (2006).

32. Tas M., Balcı M., Yuksel A., Sahin Yesilcubuk N. Consumer Awareness, Perception And Attitudes Towards Genetically Modified Foods In Turkey". British Food Journal: 117: 1426-39: (2015).

33. Ozdemir O., Gunes M.H., Demir S. University Students Of Genetically Modified Organisms (GMOs) For Knowledge - Attitude And Be Evaluated In Terms Of Sustainable Consumption. OMU Education Journal: $29:$ 53-68: (2010).

34. Zajac J., Chomoncik M., Kolarzyk E., Ogonowska D. Controversial Issue in Bio-technology-Students' Opinions. Przeglad Lek.: 69 (8): 459: (in Polish; English abstract): (2012).

35. Xia J., Song P., Xu L., Tang W. Retraction of a Study on Genetically Modified Corn: Expert Investigations Should Speak Louder during Controversies over Safety. Biosci Trends: 9 (2): 134: (2015).

36. Montuori P., Triassi M., Sarnacchiaro P. The consumption of genetically modified foods in Italian high school students. Food Quality and Preference: 26: 246-51: (2012). 